\title{
Endomycorrhizal fungus in chlorophyll-free and green forms of the terrestrial orchid Epipactis helleborine
}

\author{
AULIKKI SALMIA
}

\begin{abstract}
SALMIA, A. 1988: Endomycorrhizal fungus in chlorophyll-free and green forms of the terrestrial orchid Epipactis helleborine. - Karstenia 28: 3-18.

A brown, slowly growing unidentified fungus was isolated from nine (chlorophyll-free, yellowish-green and green) individuals of Epipactis helleborine (L.) Cranz collected from Finland. The brown fungus appeared regularly from sterilized root segments, and four isolates were obtained from hyphal coils in cortical cells of both green and white individuals. The results indicate that the same endophyte inhabited white and green plants of $E$. helleborine, and that the brown fungus can be considered to be the endophyte of this species, though this has not yet been confirmed with symbiotic tests. The effect of different surface-sterilizing agents on the appearance of the brown fungus from root pieces was investigated. The most suitable sterilization chemical proved to be $0.1 \%$ mercuric chloride in 50\% ethanol. The morphology and some characteristics of the fungus are described. The growth pattern and microscopic chracateristics of the brown endophyte differ from those of the well-known orchid fungi. No teleomorph could be obtained in culture.
\end{abstract}

Aulikki Salmia, Department of Botany, University of Helsinki, Unioninkatu 44, SF00170 Helsinki, Finland

\section{Introduction}

Under natural conditions, the absorbing organs, roots or rhizomes of most members of the Orchidaceae are infected by intracellular fungi, which form coils of hyphae within the cortical cells. Successful isolation of the endophyte depends on the methods used (e.g. surface sterilizing, media), degree of infection and viability of the hyphal coils. Probably due to its efficiency, mercuric chloride (usually in water) has been widely used as sterilizing agent in many orchids (Burges 1939, Curtis 1939, Downie 1959, Smith 1966, Harvais \& Hadley 1967). Other chemicals that have been used for orchid root pieces are $9 \%$ hydrogen peroxide (Alexander \& Hadley 1983), $0.4 \%$ silver nitrate (Filipello Marchisio et al. 1985), sodium or calcium hypochlorite (Harvais 1974, Barroso et al. 1986a, b) and ethanol (Nieuwdorp 1972). If mature plants are infected by viable coils, the endophytic fungi can be fairly easily isolated from roots, especially in early or mid-summer. A considerable number of orchid fungi have been obtained in culture, usually by using potato dextrose agar or some other medium such as malt, cornmeal, or Dox-yeast agar
(Burgeff 1936, Curtis 1939, Downie 1959, Smith 1966, Harvais \& Harley 1967, Warcup \& Talbot 1967, Hadley 1970, Warcup 1981a, Terashita 1982, Alexander \& Hadley 1983, Filipello Marchisio et al. 1985, Currah 1987).

Almost all the fungi isolated, especially those from green orchids, have been assigned to the form genus Rhizoctonia. The generic complex of Rhizoctonia is, however, rather variable and ill-defined (Parmeter \& Whitney 1970, Tu \& Kimbrough 1975). Perfect stages of Rhizoctonia are known to belong to the Basidiomycetes and Ascomycetes (see e.g. Whitney \& Parmeter 1964, Warcup 1975). Species in the Rhizoctonia complex produce a wide variety of teleomorphs belonging to several families of the Basiodiomycetes, such as the Tulasnellaceae (Tulasnella spp.), Ceratobasidiaceae (Ceratobasidium spp., Thanatephorus spp., Ypsilonidium spp.) and Tremellaceae (Sebacina vermifera) (see Warcup \& Talbot 1966, 1967, Harley 1969, Warcup \& Talbot 1971, Warcup 1975, Tu \& Kimbrough 1978, Arditti 1979, Warcup \& Talbot 1980, Warcup 1981b, Hadley 1982, Harley \& Smith 1983). 
"Corticium catonii" (Burgeff 1936) and Favolaschia dybowskyana (Jonsson \& Nylund 1979), which both belong to the Aphyllophorales, have been shown to be mycorrhizal with orchids. Clamp-forming and other Basidiomycetous genera which do not belong to the Rhizoctonia complex have been identified, for instance, in achlorophyllous orchids: Marasmius coniatus in Didymoplexis minor (Burgeff 1959), Armillaria mellea in Galeola septentrionalis (Hamada 1939, see also Terashita 1985) and in Castrodia cunninghamii (Campbell 1962), Fomes spp. in Galeola hydra (Burgeff 1959) and in Gastrodia sesamoides (Campbell 1964), and Hymenochaete crocicreas in Galeola altissima (Hamada \& Nakamura 1963). Three strains of Ascomycetes with rhizoctoniaiceous anamorphs have been isolated from Pterostylis species in Australia, but all attempts to germinate Pterostylis seeds with them have been unsuccessful (Warcup 1975). The presence of some Ascomycetes as endophytes has been established in tropical orchid epiphytes (Petrini \& Dreyfuss 1981, Dreyfuss \& Petrini 1984). A vesicular-arbuscular mycorrhiza has even been reported in the orchid Corybas macranthus (Hall 1976).

Many reports of the endophytic fungi of European orchids are fairly old and sporadic and the attempts to obtain perfect stages of Rhizoctonia -like or other orchid fungi in culture have often been unsuccessful (see e.g. Filipello Marchisio et al. 1985). For instance, the perfect stages of the endophytes of the European saprophytic orchids are still unknown (see however Campbell 1970). Without the perfect stage, the identification is extremely difficult and unsure and can be made only by comparing the data with those in the literature. In some European green orchids, however, endomycorrhizal fungi have been identified. Rhizoctonia goodyerae-repentis (perfect stage Ceratobasidium cornigerum, cf. Warcup \& Talbot 1966) has been isolated from Goodyera repens (Downie 1940, Hadley 1970, Alexander \& Hadley 1983), Rhizoctonia solani ("Corticium solani", perfect stage Thanatephorus cucumeris, cf. Warcup \& Talbot 1967) from Dactylorchis purpurella (cf. Downie 1957, 1959, Harvais \& Hadley 1967) and from Coeloglossum viride (Harvais \& Hadley 1967), Thanatephorus orchidicola from Orchis mascula (Warcup \& Talbot 1966) and from Coeloglossum viride (Warcup \& Talbot 1967), Thanatephorus pennatus from Calypso bulbosa (Currah 1987), and Rhizoctonia repens (perfect stage Tulasnella calospora) from Dactylorchis purpurella, Dactylorchiza maculata and Plantanthera bifolia (Warcup \& Talbot 1967, Harvais \& Hadley 1967, Hadley 1970).

Some orchid endophytes, e.g. Ceratobasidium cornigerum, are terrestrial saprophytes (Downie
1943, Warcup \& Talbot 1962, 1965, 1966, 1967) and can grow freely in soil, or they may be parasitic on a variety of hosts, e.g. Thanatephorus cucumeris (Rhizoctonia solani) and Armillaria mellea (Domsch et al. 1980). Mycorrhizal infection of orchids differs from other kinds (VA, ectotrophic) in one fundamental respect (Harley \& Smith 1983). The net movement of carbon compounds is from the substrate through the fungus into the host. In other forms of mycorrhiza, carbon compounds originate in photosynthesis by the host and their net movement is into the fungus (Harley \& Smith 1983).

In Lappeenranta, SE Finland, a population of Epipactis helleborine growing on a hill with Scots pine as the dominant tree was found to contain normal green, yellowish-green and abundant white chlorophyll-free individuals (Salmia 1986). All the plants investigated were regularly and uniformly infected by a brown endophytic fungus, which was readily seen in whole mounts of root sections (Salmia 1989). As both the green and chlorophyll-free plants of $E$. helleborine were shown to be infected, it was interesting to find out whether the fungi were identical, too. This paper deals with the isolation and properties of the endophytic fungi of the white and green plants.

\section{Plant material}

Mature plants of the broad-leaved helleborine (Epipactis helleborine (L.) Cranz) were collected from Lappeenranta, Finland; on 24 July 1981 (two plants, chlorophyll-free and normal green) and on 31 July 1982 (8 plants: chlorophyll-free 1a-c; yellowishgreen $2 \mathrm{a}$, b; normal green $3 \mathrm{a}-\mathrm{c}$ ). For the site and other details, see Salmia $(1986,1989)$. In addition, two normal green plants were collected on 20 October 1982 from Strömnäs, Kemiö, Finland; from sunny calcareous bedrock with scattered Scots pines. The field layer of the latter site contains Asplenium rutamuraria, A. septentrionalis, Woodsia ilvensis, and Geranium sanguineum (B. Lindén, pers. comm.). The localities, Lappeenranta and Kemiö, are ca. 330 $\mathrm{km}$ apart. The plants were carefully removed from the ground to ensure that the root system was kept intact. $E$. helleborine has abundant long straight roots, the colour ranging from light to dark brown (Salmia 1986, Fig. 6). The plants were grown in pots in a greenhouse until the isolation of the fungi was performed.

\section{Isolation of endophyte(s)}

Preliminary studies, plants collected in 1981. Two attempts were made to isolate the endo- 
phyte(s) of Epipactis helleborine. For mild sterilizing, the root pieces were submerged in $70 \%$ ethanol (1-5 min) and washed with sterile water. Another trial included sterilizing in $70 \%$ ethanol for $3 \mathrm{~min}$, and several other surface-sterilizing methods: $0.1 \%$ mercuric chloride in water $2 \mathrm{~min}, 1 \% \mathrm{AgNO}_{3} 1 \mathrm{~min}$, subsequent washing with $4 \% \mathrm{NaCl}(1 \mathrm{~min})$, then washing three times with sterile water, $2 \%$ chloramin T.

After surface sterilization, the root segments were cut aseptically into small pieces (ca. $5 \mathrm{~mm}$ in length). The pieces were placed in threes in Petri dishes containing potato-dextrose agar (PDA, Difco) or PDA + 50 ppm streptomycin (Merck).

Studies on plants collected in 1982. As none of the fungi isolated in 1981 (Table 3) looked like the endophyte occupying the root cortex cells, the isolation trial was repeated in 1982, but on a larger scale. Two kinds of material were chosen:

A) Root segments: 10 roots of the plants collected from Lappeenranta were surface sterilized with five chemicals according to Gams et al. (1980):

a) $0.1 \%$ mercuric chloride in $50 \%$ ethanol/2 $\min +30 \mathrm{~min}$ subsequent washing in sterile water,

b) $0.1 \%$ mercuric chloride in water $/ 2 \mathrm{~min}+30$ min subsequent washing in sterile water,

c) $1 \% \mathrm{AgNO}_{3} / 1 \mathrm{~min}+1 \mathrm{~min}$ washing with $4 \%$ $\mathrm{NaCl}+30$ min washing with sterile water,

d) $70 \%$ ethanol/3 min + washing with sterile water,

e) $0.4 \% \mathrm{NaOCl} / 2 \mathrm{~min}+10 \mathrm{~min}$ washing with sterile water.

The roots of the plants from Kemiö were sterilized only with chemicals $a, b$, and $d$. The sterilized pieces were cut into two to three 5-mm-long fragments and placed in Petri dishes containing PDA, 50 ppm streptomycin and $50 \mathrm{ppm}$ penicillin $\mathrm{G}$ (Hoechst).

B) Hyphal coils: The roots were surface-sterilized with $70 \%$ ethanol for $3 \mathrm{~min}$, then cut through longitudinally. The cells having hyphal coils were scraped out aseptically into a drop of water and then transferred to dishes containing PDA.

All dishes were incubated at $18-20^{\circ} \mathrm{C}$ in the dark. Possible growth of mycelia from the samples was followed first daily, then two to three times a week, then weekly and later on monthly. Cultures on PDA were left for 2-3 months to allow development of monilioid hyphae and chlamydospores. Mycelia were subcultured at approximately 2 -month intervals. Sixteen of the isolates were later transferred to fresh
PDA and cornmeal agar (CMA, Difco). The growth rates of these isolates were determined by measuring the radial increase in two directions, first weekly during a 5-week period, then after 2 months. The diameters of hyphae, monilioid cells and chlamydospores were measured in glycerol-water.

\section{Results}

\section{Effect of sterilizing agents on the fungi}

The over 700 root pieces sectioned out of eight plants (Lappeenranta/1982) yielded 72 occurrences of a brown, very slowly growing fungus (Table 1). Of the isolates obtained, $54 \%$ were from white, $13 \%$ from yellowish-green, and $33 \%$ from green plants. The brown fungus appeared 4 to 25 times from each plant (Table 1). This regular occurrence strongly suggests that the brown fungus plays the role of an endophyte.

The majority of the brown isolates, 94\%, were obtained with $0.1 \%$ mercuric chloride as a surfacesterilizing agent (Figs. 1, 3-6), but ca. 60\% of the total root material showed no fungal growth after this treatment. Such root pieces seemed to be quite sterile even after 4 months on PDA. The effectiveness of mercuric chloride as a surface-sterilizing chemical gives further support to the conclusion that the brown fungus is an endophyte. Silver nitrate seemed to be too effective and quite unsuitable: over $90 \%$ of the roots were totally sterile, and the brown fungus appeared only once (Table 1, Fig. 2). With the milder chemicals, $70 \%$ ethanol (Fig. 7) and $0.4 \%$ sodium hypochlorite, the brown fungus appeared only twice and once, respectively. With these chemicals abundant common soil fungi (e.g. Mortierella nana, Humicola fuscoatra) and moulds emerged in the cultures within a few days. The flush of these fungi evidently prevented growth of the brown endophyte.

The 108 root pieces made from the two orchid specimens of Kemiö/1982 yielded only one occurrence of the brown fungus (Fig. 8, Table 2). The strain was obtained using $0.1 \% \mathrm{HgCl}_{2}$ in $50 \%$ ethanol as the surface-sterilizing agent.

The plants of Lappeenranta/1981 did not produce the brown fungus (Table 3 ). Though at first perplexing, this result may have several explanations. Most probably, the material was too small to produce the endophyte, or the isolations were made too late after collection. Many different common soil fungi appeared in the cultures, e.g. pure white Mortierella nana, black Humicola fuscoatra, brown Cylindrocarpon destructans, brownish Morchella sp., blackish Sordaria fimicola, plus many unidentified moulds (Table 

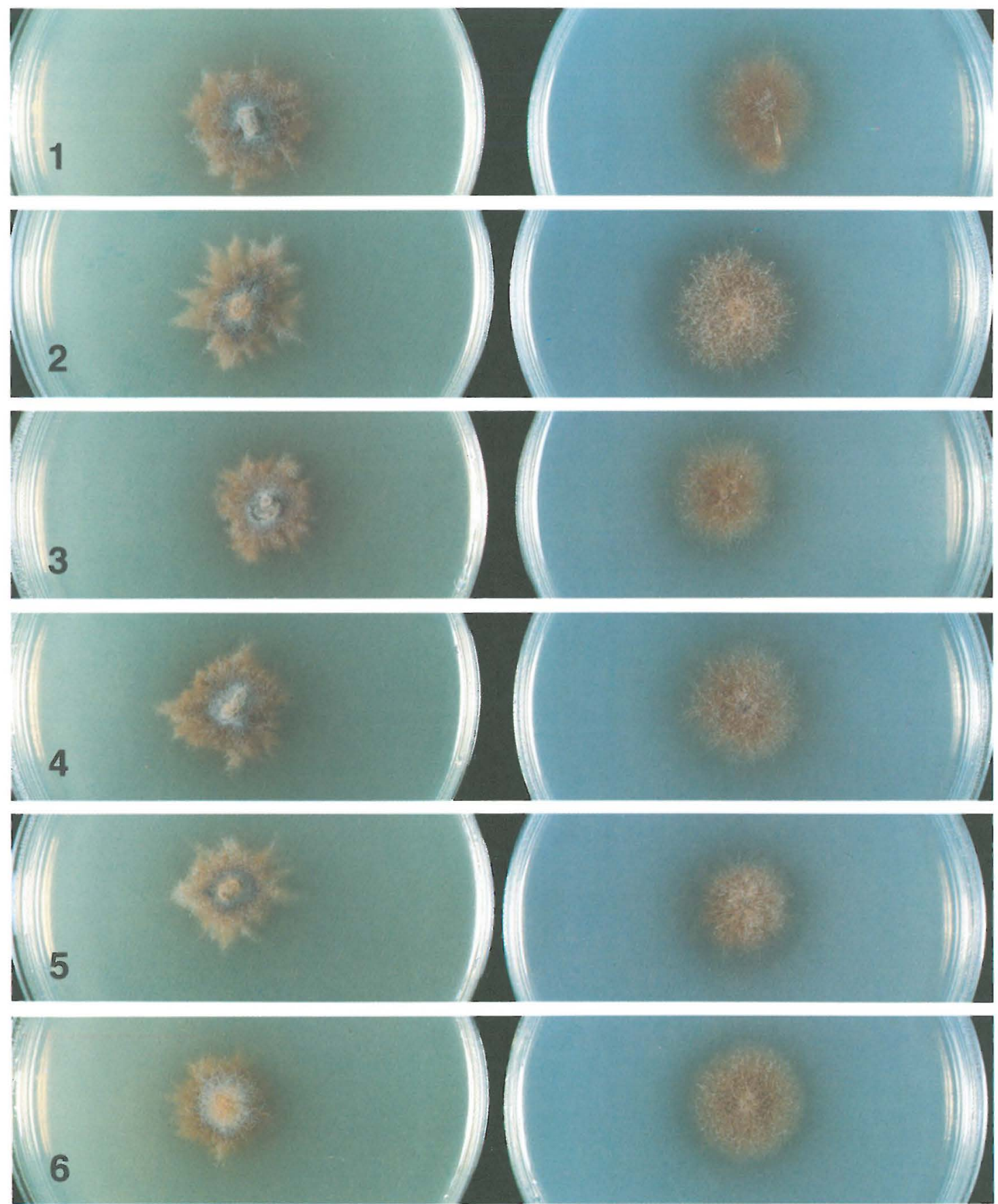

Figs. 1-12. Growth of some isolates of the brown endophyte. During one month (31 days) in $90 \mathrm{~mm}$ Petri dishes on PDA (left) and CMA (right). - 1-7. Isolated from root sections of specimens collected from Lappeenranta. Surface-sterilization of root sections with mercuric chloride (Figs.1, 3-6), silver nitrate (Fig. 2) or 70\% ethanol (Fig. 7). - 1: White plant (207/1a). - 2: Another white plant $(142 / 1 \mathrm{c})$. - 3: Yellowish-green plant (90/2a). - 4: Another yellowish-green plant (293/2b). - 5: Green plant (48/3a). - 6: Another green plant (257/3b). 

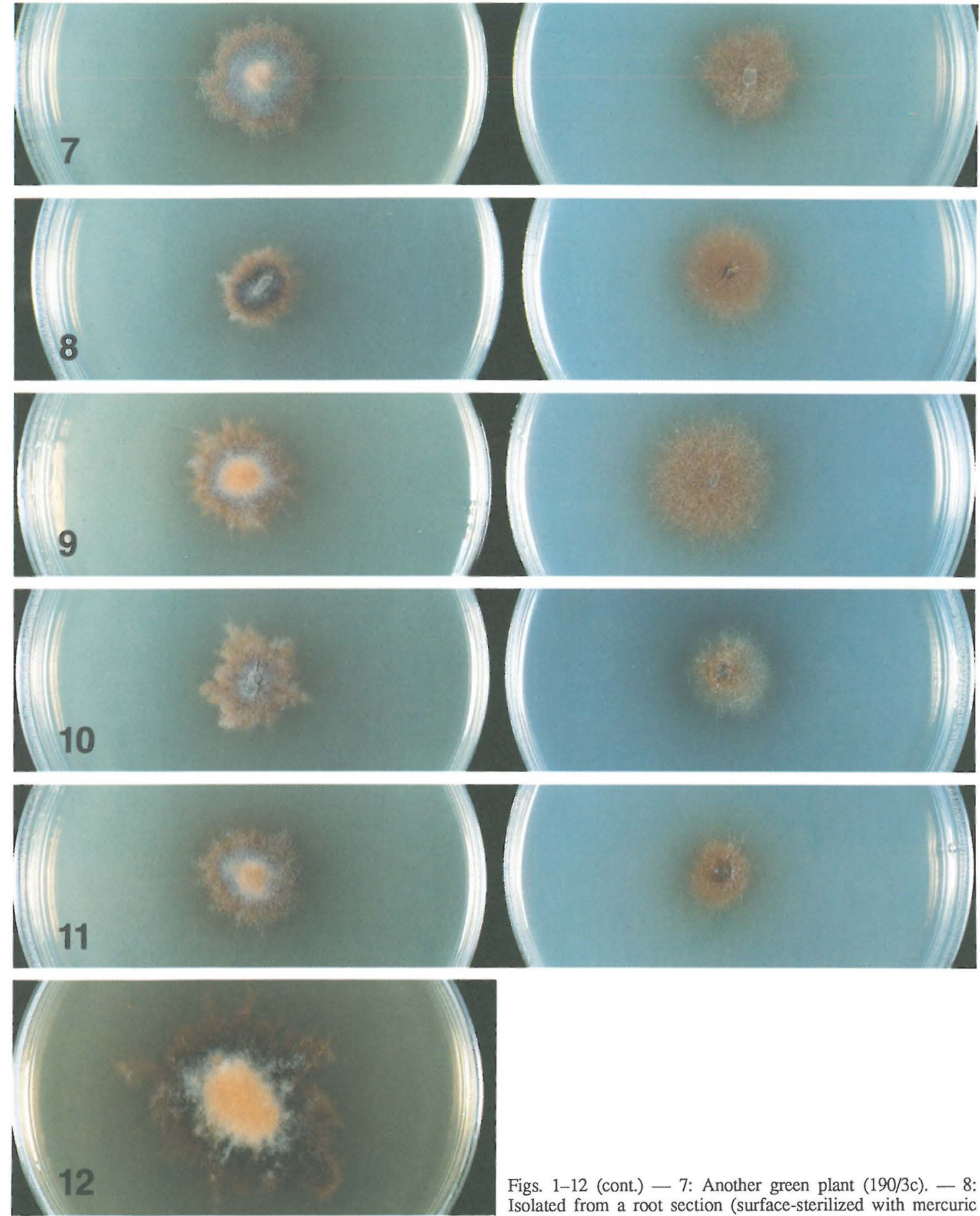

Figs. 1-12 (cont.) - 7: Another green plant (190/3c). - 8: Isolated from a root section (surface-sterilized with mercuric chloride) of a green plant collected from Kemiö (421/K). 9-12. Isolated from hyphal coils. - 9: Green plant (543/3c). - 10: White plant (346/1b). - 11: Another white plant (493/1c). - 12: Growth of a brown isolate (same as in Fig. 11) during three months on PDA. 
Table 1. Fungi isolated from small root pieces of white, yellowish-green and green specimens of Epipactis helleborine, collected from Lappeenranta in 1982. Ten roots per plant were washed and cut into five ca. 1.5-cm pieces, which were surface-sterilized with five chemicals. The sterilized pieces were cut into two to three 5-mm fragments and placed aseptically in Petri dishes (40 per plant) containing PDA, two to three fragments per dish. The numerals are the number of Petri dishes whose roots showed mycelial growth. If more than one fragment in a dish showed growth, the number is given in brackets. $\mathrm{M}, \mathrm{H}$, and $\mathrm{Y}$ refer to Mortierella nana, Humicola fuscoatra, and a yeast-like fungus, respectively. Dates of isolation: 3-5 August 1982.

\begin{tabular}{|c|c|c|c|c|c|c|c|c|c|c|c|}
\hline \multirow{2}{*}{$\begin{array}{l}\text { Surface } \\
\text { steril. } \\
\text { used }\end{array}$} & \multirow{2}{*}{$\begin{array}{l}\text { No. of } \\
\text { roots } \\
\text { (plant) }\end{array}$} & \multirow[t]{2}{*}{$\begin{array}{l}\text { Fungus } \\
\text { isolated }\end{array}$} & \multicolumn{8}{|c|}{ Plants } & \multirow{2}{*}{$\begin{array}{l}\text { Total } \\
8 \text { plants }\end{array}$} \\
\hline & & & $1 \mathrm{a}$ & $1 b$ & $1 \mathrm{c}$ & $2 a$ & $2 \mathrm{~b}$ & $3 a$ & $3 b$ & $3 c$ & \\
\hline \multirow{5}{*}{$\begin{array}{l}\text { Mercuric } \\
\text { chloride } \\
(0.1 \%) \\
\text { in ethanol }\end{array}$} & \multirow[t]{5}{*}{10} & Brown endophyte & $5(11)$ & $3(5)$ & $4(7)$ & $1(1)$ & $2(3)$ & $3(3)$ & $4(6)$ & $4(8)$ & $26(44)$ \\
\hline & & Others $(\mathrm{M}, \mathrm{H}, \mathrm{Y})$ & 0 & 0 & 0 & 0 & 0 & $1 \mathrm{H}, 1 \mathrm{Y}$ & $1 \mathrm{M}$ & $1 \mathrm{H}, 1 \mathrm{Y}$ & 5 \\
\hline & & Moulds, etc. & 0 & 1 & 0 & 2 & 0 & 0 & 0 & 1 & 4 \\
\hline & & No fungal growth & 5 & 6 & 6 & 7 & 8 & 5 & 5 & 3 & 45 \\
\hline & & Total & 10 & 10 & 10 & 10 & 10 & 10 & 10 & 10 & 80 \\
\hline \multirow{5}{*}{$\begin{array}{l}\text { Mercuric } \\
\text { chloride } \\
(0.1 \%) \\
\text { in water }\end{array}$} & \multirow[t]{5}{*}{10} & Brown endophyte & $8(14)$ & 0 & $1(1)$ & $2(2)$ & $2(2)$ & $1(1)$ & $2(2)$ & $2(2)$ & $18(24)$ \\
\hline & & Others $(\mathrm{M}, \mathrm{H}, \mathrm{Y})$ & 0 & 0 & $1 \mathrm{H}, 2 \mathrm{Y}$ & 0 & $1 \mathrm{M}$ & 0 & $1 \mathrm{M}$ & $2 Y$ & 7 \\
\hline & & Moulds, etc. & 1 & 0 & 0 & 0 & 0 & 3 & 2 & 1 & 7 \\
\hline & & No fungal growth & 1 & 10 & 6 & 8 & 7 & 6 & 5 & 5 & 48 \\
\hline & & Total & 10 & 10 & 10 & 10 & 10 & 10 & 10 & 10 & 80 \\
\hline \multirow{5}{*}{$\begin{array}{l}\text { Silver } \\
\text { nitrate } \\
(1 \%)\end{array}$} & \multirow[t]{5}{*}{8} & Brown endophyte & 0 & 0 & $1(1)$ & 0 & 0 & 0 & 0 & 0 & $1(1)$ \\
\hline & & Others $(\mathrm{M}, \mathrm{H}, \mathrm{Y})$ & 0 & 0 & 0 & 0 & 0 & $2 Y$ & 0 & 0 & 2 \\
\hline & & Moulds, etc. & 1 & 0 & 0 & 0 & 0 & 1 & 0 & 0 & 2 \\
\hline & & No fungal growth & 7 & 8 & 7 & 8 & 8 & 5 & 8 & 8 & 59 \\
\hline & & Total & 8 & 8 & 8 & 8 & 8 & 8 & 8 & 8 & 64 \\
\hline \multirow{5}{*}{$\begin{array}{l}\text { Ethanol } \\
(70 \%)\end{array}$} & \multirow[t]{5}{*}{6} & Brown endophyte & 0 & 0 & 0 & 0 & 0 & 0 & $1(1)$ & $1(1)$ & $2(2)$ \\
\hline & & Others $(\mathrm{M}, \mathrm{H}, \mathrm{Y})$ & $2 Y$ & $2 \mathrm{M}, 2 \mathrm{H}$ & $2 Y$ & $1 \mathrm{H}$ & $1 Y$ & $1 \mathrm{H}, 1 \mathrm{Y}$ & $1 \mathrm{M}$ & $1 \mathrm{M}, 1 \mathrm{Y}$ & 15 \\
\hline & & Moulds, etc. & 2 & 2 & 1 & 2 & 3 & 2 & 3 & 2 & 17 \\
\hline & & No fungal growth & 2 & 0 & 3 & 3 & 2 & 2 & 1 & 1 & 14 \\
\hline & & Total & 6 & 6 & 6 & 6 & 6 & 6 & 6 & 6 & 48 \\
\hline \multirow{5}{*}{$\begin{array}{l}\text { Sodium- } \\
\text { hypo- } \\
\text { chlorite } \\
(0.4 \%)\end{array}$} & \multirow[t]{5}{*}{6} & Brown endophyte & 0 & 0 & 0 & $1(1)$ & 0 & 0 & 0 & 0 & $1(1)$ \\
\hline & & Others $(\mathrm{M}, \mathrm{H}, \mathrm{Y})$ & $4 \mathrm{H}$ & $6 \mathrm{H}$ & $3 \mathrm{H}$ & $1 \mathrm{M}, 2 \mathrm{H}$ & 0 & $1 \mathrm{M}, 3 \mathrm{H}$ & $2 \mathrm{M}, 2 \mathrm{H}$ & $5 \mathrm{H}$ & 29 \\
\hline & & Moulds, etc. & 0 & 0 & 1 & 1 & 2 & 0 & 1 & 1 & 6 \\
\hline & & No fungal growth & 2 & 0 & 2 & 1 & 4 & 2 & 1 & 0 & 12 \\
\hline & & Total & 6 & 6 & 6 & 6 & 6 & 6 & 6 & 6 & 48 \\
\hline Total & & Brown endophyte & $13(25)$ & $3(5)$ & $6(9)$ & $4(4)$ & $4(5)$ & $4(4)$ & $7(9)$ & $7(11)$ & $48(72)$ \\
\hline
\end{tabular}

3). All these fungi are known to be saprophytes or weak parasites and are very common in soil, living in root rhizospheres or on plant root surfaces (Booth 1966, Lundkvist 1972, Domsch et al. 1980). I do not consider them to be endophytes of Epipactis helleborine.
Interestingly, a pale cream-coloured fungus appeared 20 times from roots of white, yellowishgreen, and green plants collected from Lappeenranta/ 1981, 1982 (Tables 1 and 3). Its mycelium grew very slowly (Table 5), and the yeast-like cells measured $6-7 \times 5-6 \mu \mathrm{m}$. The ecology and role of this species 
Table 2. Fungi isolated from root pieces of two green individuals of Epipactis helleborine collected from Kemiö. The washed roots were cut into in ca. $1.5-\mathrm{cm}$ pieces and surface-sterilized with three different chemicals. The pieces were cut into three 5-mm-long fragments and placed in Petri dishes containing PDA. The numerals are the number of Petri dishes whose root pieces showed fungal growth. $\mathrm{C}$ refers to Cylindrocarpon destructans. Date of isolation: 1 November 1982.

\begin{tabular}{|c|c|c|c|c|c|}
\hline $\begin{array}{l}\text { Surface } \\
\text { steril. }\end{array}$ & $\begin{array}{l}\text { No. of roots } \\
\text { (per plant) }\end{array}$ & $\begin{array}{l}\text { Fungus } \\
\text { isolated }\end{array}$ & Plant 1 & Plant 2 & Total \\
\hline \multirow{5}{*}{$\begin{array}{l}\text { Mercuric } \\
\text { chloride } \\
(0.1 \%) \\
\text { in ethanol }\end{array}$} & \multirow[t]{5}{*}{6} & Brown endophyte & 0 & 1 & 1 \\
\hline & & Others (C) & 0 & $1 \mathrm{C}$ & 1 \\
\hline & & Moulds, etc. & 3 & 1 & 4 \\
\hline & & No fungal growth & 3 & 3 & 6 \\
\hline & & Total & 6 & 6 & 12 \\
\hline \multirow{5}{*}{$\begin{array}{l}\text { Mercuric } \\
\text { chloride } \\
(0.1 \%) \\
\text { in water }\end{array}$} & \multirow[t]{5}{*}{6} & Brown endophyte & 0 & 0 & 0 \\
\hline & & Others & 0 & 0 & 0 \\
\hline & & Moulds, etc. & 3 & 2 & 5 \\
\hline & & No fungal growth & 3 & 4 & 7 \\
\hline & & Total & 6 & 6 & 12 \\
\hline \multirow{5}{*}{$\begin{array}{l}\text { Ethanol } \\
(70 \%)\end{array}$} & \multirow[t]{5}{*}{6} & Brown endophyte & 0 & 0 & 0 \\
\hline & & Others & 0 & 0 & 0 \\
\hline & & Moulds, etc & 6 & 6 & 12 \\
\hline & & No fungal growth & 0 & 0 & 0 \\
\hline & & Total & 6 & 6 & 12 \\
\hline
\end{tabular}

are obscure, and it remained unidentified in Centraalbureau voor Schimmelcultures, Baarn, the Netherlands.

\section{Occurrence of the hyphal coil endophyte}

Less than $5 \%$ of the hyphal coils scraped out of the root cortex showed fungal growth. This low percentage was mostly due to bacterial contamination. In addition some coils were probably not viable, as they showed no growth on plates during several months. However, in four cases (white 1b, c and green $3 c$ ), isolates of the brown fungus were obtained from the coils as well (Figs. 9-12, Table 4).

\section{Description of the endophyte}

Within the roots. Intracellular hyphae hyaline to brown, ramified in the cortical cells, smooth, always septate, usually $3-6(-7) \mu \mathrm{m}$ in diam, readily observed in whole mounts (Fig. 13, see also Salmia 1989). Hyphal cells $13-30 \mu \mathrm{m}$ long. Hyphae pene- trating through cortical cell walls and proceeding from cell to cell. Clamydospores or monilioid cells not seen inside the root cortex cells.

Brown, septate, smooth or verrucose, 3-7 $\mu \mathrm{m}$ wide hyphae were observed outside the root epidermis. Microscopy showed that some external hyphae were penetrating or had penetrated the epidermal cells or root hairs. Within the root cells the hyphae were always smooth.

In culture. The start of hyphal growth was very slow in all of the 77 isolates (Table 4). The first hyphae became visible only after one week (Table 4). Half of the sterilized root pieces or isolated hyphal clumps had hyphal growth after 7 to 14 days (Table 4).

The further growth of the brown fungus was very slow, too. After ca. one month the average colony diameters on PDA were 1-2 cm, after ca. 2 months 3 to $4(-5) \mathrm{cm}$ (Table 5, Figs. 1-12). Isolates from hyphal coils and from root fragments grew at the same speed, and except for one isolate (18/1b on CMA, Table 5), the radial increase was similar in of all the 

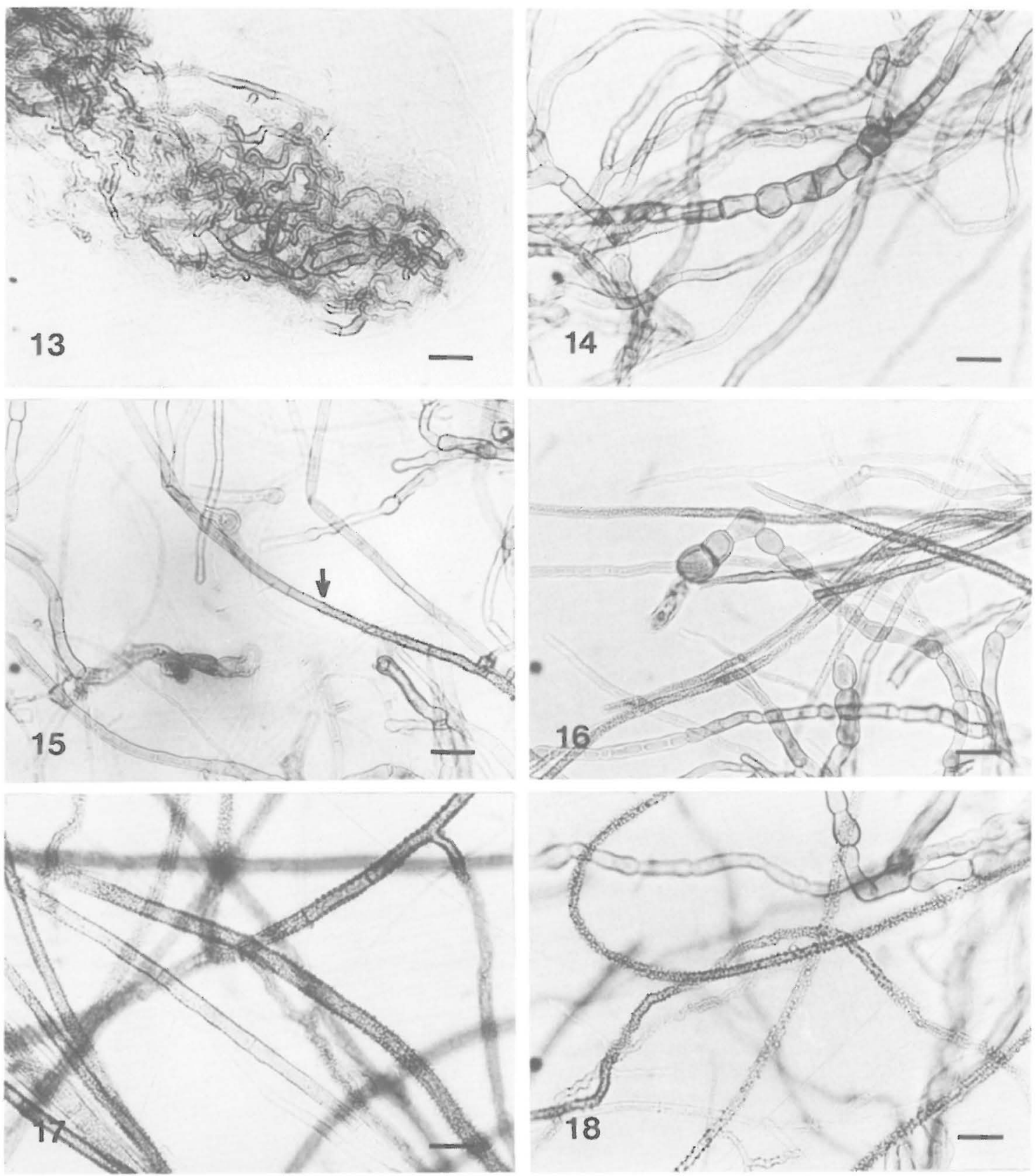

Figs. 13-24. The endophyte of E. helleborine. - 13: Cortical cell from a green individual (3a) showing the endophyte. - 14-24. Morphology of hyphae, monilioid hyphae, and chlamydospores of the brown endophyte isolated from root sections or from hyphal coils. All isolates were grown on PDA. Bar indicates $20 \mu \mathrm{m}$. - 14: Smooth hyphae and monilioid hyphae (hyphal coil, white individual, code 493/1c). - 15: Straight hyphae and hyphae with swollen terminals. Arrow indicates transition from smooth to verrucose hyphae (root section, yellowish-green plant, code 293/2b). - 16: Smooth and verrucose hyphae and monilioid cells (hyphal coil, white individual, code 493/1c). - 17: Verrucose hyphae (root section, white plant, code 142/1c). - 18: Verrucose hyphae and hyphae with swollen terminals (root section, green plant from Kemiö, code 421/K). 

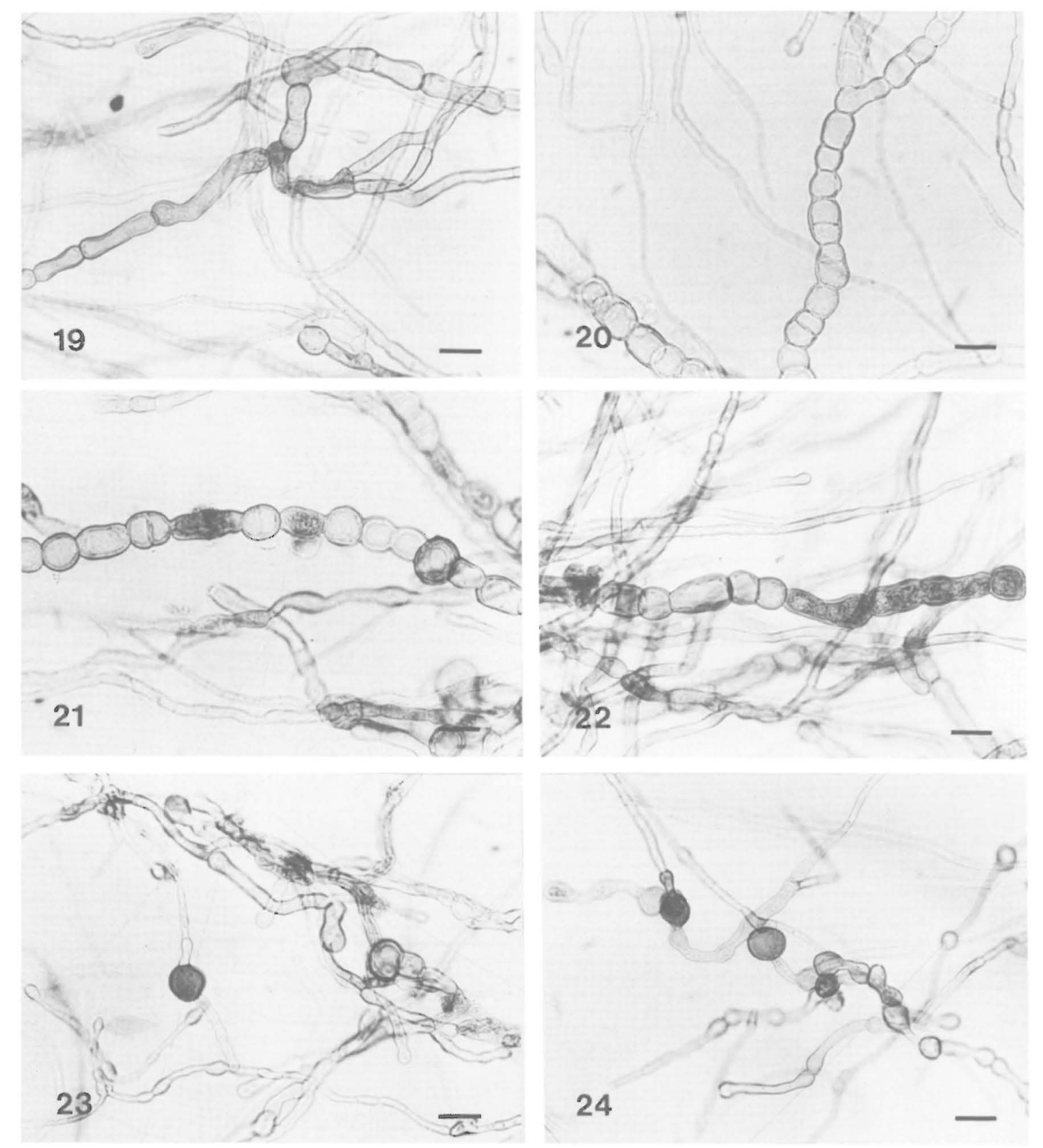

Figs. 13-24 (cont.) - 19: Hyphae with swollen terminals (hyphal coil, white individual, code 493/1c). — 20: Monilioid hyphae (root section, yellowish-green plant, code 90/2a). - 21: Monilioid hyphae (root section, green plant from Kemiö, code 421/K). 22: Monilioid hyphae and developing chlamydospores (hyphal coil, white individual, code 493/1c). — 23: Hyphae and chlamydospores (root section, white individual, code 140/1c). - 24: Hyphae and chlamydospores (root section, green individual, code 48/3a). 
Table 3. Fungi isolated from small root pieces of a green and a white plant of Epipactis helleborine collected from Lappeenranta in 1981. Dates of isolation: A) 27.VII.1981, B) 31.VIII.1981.

\begin{tabular}{|c|c|c|c|c|}
\hline $\begin{array}{l}\text { Surface } \\
\text { sterilizing }\end{array}$ & Plant & $\begin{array}{l}\text { No. of roots } \\
\text { used as material }\end{array}$ & Fungi isolated & $\begin{array}{l}\text { No. of roots } \\
\text { showing funga } \\
\text { growth }\end{array}$ \\
\hline \multirow{4}{*}{$\begin{array}{l}\text { A) Ethanol, } \\
70 \%\end{array}$} & White & 5 & Mortierella nana & $5 / 5$ \\
\hline & Green & 5 & Mortierella nana & $5 / 5$ \\
\hline & & & Humicola fuscoatra & $2 / 5$ \\
\hline & & & Morchella sp. & $2 / 5$ \\
\hline \multirow{4}{*}{$\begin{array}{l}\text { B) Ethanol, } \\
70 \%\end{array}$} & White & 2 & Mortierella nana & $1 / 2$ \\
\hline & & & Humicola fuscoatra & $1 / 2$ \\
\hline & Green & 2 & Mortierella nana & $2 / 2$ \\
\hline & & & Humicola fuscoatra & $1 / 2$ \\
\hline \multirow[t]{2}{*}{ Chloramin T } & White & 2 & Cylindrocarpon destructans & $1 / 2$ \\
\hline & Green & 2 & Mortierella nana & $1 / 2$ \\
\hline \multirow[t]{2}{*}{$\mathrm{AgNO}_{3}$} & White & 3 & Cylindocarpon destructans & $2 / 3$ \\
\hline & Green & 3 & Cylindrocarpon destructans & $1 / 3$ \\
\hline \multirow[t]{4}{*}{$\mathrm{HgCl}_{2}$} & White & 3 & Yeast-like (unidentified) & $1 / 3$ \\
\hline & Green & 3 & Yeast-like (unidentified) & $2 / 3$ \\
\hline & & & Morchella sp. & $1 / 3$ \\
\hline & & & Sordaria fimicola & $1 / 3$ \\
\hline
\end{tabular}

Table 4. Beginning of hyphal growth of the brown fungus from the sterilized root pieces or isolated hyphal clumps on PDA. Time indicates the period which elapsed before the first hyphae were seen by the naked eye. $\mathrm{L}$ and $\mathrm{K}$ denote Lappeenranta and Kemiö, respectively.

\begin{tabular}{lrcccrr}
\hline Days & \multicolumn{2}{c}{ Root sections } & \multicolumn{2}{c}{ Hyphal coils } & Total & $\%$ \\
& L & K & L & K & & \\
\hline $0-7$ & 0 & 0 & 0 & 0 & 0 & 0 \\
$7-14$ & 37 & 0 & 1 & 0 & 38 & 49 \\
$15-21$ & 17 & 0 & 2 & 0 & 19 & 25 \\
$22-28$ & 9 & 1 & 0 & 0 & 10 & 13 \\
$29-35$ & 4 & 0 & 1 & 0 & 5 & 6 \\
$36-42$ & 2 & 0 & 0 & 0 & 2 & 3 \\
$>43$ & 3 & 0 & 0 & 0 & 3 & 4 \\
Total & 72 & 1 & 4 & 0 & 77 & 100 \\
\hline
\end{tabular}

brown isolates. The colour of the mycelium on PDA ranged from café au lait to dark brown, staining the agar deep brown in old cultures (Fig. 12). The myce- lium was opaque, densely cottony, and with an irregular, lacunose margin. On CMA the mycelium was brown, cottony, with a regular margin, staining the agar only faintly.

Twenty isolates were studied in the microscope (Table 6). They looked very similar, even the strain $421 / \mathrm{K}$ from the distant locality in Kemiö. On both media the hyphae were septate, approximately (2-)3$5(-8) \mu \mathrm{m}$ in diam (Table 6, Figs. 14-18), long-celled $(20-50(-66) \mu \mathrm{m})$, in young cultures thread-like and hyaline, in older cultures hyaline to brown, thick- and brown-walled, usually smooth. The hyphae arising from the inocululum on PDA and CMA, however, were often ornamented or verrucose, hyaline to brown (see Figs. 16-18). All hyphae were straight and rather rarely branched, the angle of hyphal branching usually being $90^{\circ}$. Some hyphae had swollen septal regions (Figs.15, 18, 19, 23, 24). Globose cells in monilioid hyphae were regularly seen in all cultures (Table 6, Figs. 14, 16, 20-22), often differentiating from the swollen septal regions. The monilioid cells were in chains or solitary, and had either thin and colourless or rather thick and yellowish walls. These globose to subglobose (ca. $17 \times 14 \mu \mathrm{m}$; 
Table 5. Growth rates of the brown endophyte and some other fungi. The numbers are mean values of (mostly) two replicates. PDA and CMA refer to potato-dextrose and cornmeal agar. 1a-c refer to white, $2 \mathrm{a}, \mathrm{b}$ to yellowish-green, and $3 a-c$ to green individuals of the broad-leaved helleborine collected from Lappeenranta in 1982. $\mathrm{K}$ denotes a green plant, collected from Kemiö in 1982. E-15 refers to an ectendotrophic strain isolated from Scots pine (cf. Laiho 1965), E-24 to another ectendotrophic strain from Scots pine (cf. Mikola 1965), E-57 to a strain ectendotrophic on Scots pine and ectotrophic on spruce; E-57 was isolated from spruce (Mikola 1965). Y125 and $Y-73$ refer to the unidentified yeast-like fungus obtained from roots of $E$. helleborine.

\begin{tabular}{|c|c|c|c|c|c|c|c|c|c|}
\hline \multirow[t]{2}{*}{$\begin{array}{l}\text { Isolate } \\
\text { Code }\end{array}$} & \multirow{2}{*}{ Source } & \multicolumn{8}{|c|}{ Colony diameter $(\mathrm{mm})$ at $18-19^{\circ} \mathrm{C}$ after } \\
\hline & & PDA & CMA & PDA & CMA & PDA & CMA & PDA & CMA \\
\hline $207 / 1 \mathrm{a}$ & root piece & 6 & 6 & 12 & 11 & 18 & 16 & 27 & 25 \\
\hline 208/1a & root piece & 7 & 6 & 18 & 14 & 21 & 20 & 30 & 29 \\
\hline $18 / 1 b$ & root piece & 6 & 7 & 14 & 24 & 18 & 34 & 24 & 44 \\
\hline $346 / 1 b$ & hyphal coil & 6 & 3 & 13 & 7 & 16 & 10 & 20 & 13 \\
\hline $140 / 1 \mathrm{c}$ & root piece & 5 & 5 & 13 & 7 & 17 & 10 & 23 & 13 \\
\hline $142 / 1 \mathrm{c}$ & root piece & 6 & 8 & 15 & 15 & 22 & 22 & 27 & 26 \\
\hline $493 / 1 c$ & hyphal coil & 7 & 5 & 13 & 9 & 18 & 14 & 20 & 16 \\
\hline $90 / 2 a$ & root piece & 6 & 5 & 13 & 13 & 17 & 18 & 22 & 25 \\
\hline $293 / 2 b$ & root piece & 7 & 6 & 13 & 13 & 19 & 18 & 24 & 27 \\
\hline $48 / 3 a$ & root piece & 5 & 5 & 10 & 10 & 16 & 14 & 24 & 20 \\
\hline $257 / 3 b$ & root piece & 6 & 5 & 12 & 12 & 17 & 18 & 20 & 28 \\
\hline $176 / 3 c$ & root piece & 7 & 6 & 16 & 10 & 20 & 17 & 24 & 26 \\
\hline $190 / 3 c$ & root piece & 7 & 5 & 14 & 11 & 18 & 16 & 23 & 20 \\
\hline $542 / 3 c$ & hyphal coil & 7 & 3 & 14 & 11 & 20 & 17 & 30 & 24 \\
\hline $543 / 3 c$ & hyphal coil & 7 & 8 & 12 & 13 & 20 & 22 & 27 & 29 \\
\hline $421 / \mathrm{K}$ & root piece & 5 & 6 & 10 & 11 & 11 & 18 & 16 & 26 \\
\hline E-15 & pine root & 3 & 3 & 27 & 25 & 40 & 43 & 50 & 57 \\
\hline E-24 & pine root & 11 & 3 & 27 & 20 & 40 & 34 & 55 & 47 \\
\hline E-57 & spruce root & 21 & 29 & 50 & 53 & $>90$ & & $>90$ & \\
\hline $\mathrm{Y}-125 / 1 \mathrm{c}$ & root piece & 7 & 7 & 15 & 16 & 20 & 24 & 25 & 24 \\
\hline$Y-73 / 3 a$ & root piece & 7 & 7 & 15 & 13 & 20 & 21 & 27 & 23 \\
\hline
\end{tabular}

cf. Table 6) cells were always smooth. Chlamydospores were seen regularly, especially in old cultures on PDA. It appears that the chlamydospores emerge from the monilioid cells (Figs. 21, 22). The mature chlamydospores were dark brown and thick-walled, almost globose (ca. $19 \times 18 \mu \mathrm{m}$, Table 6), smooth (Figs. 23-24) and mostly arranged in short chains. Besides these intercalary spores in chains, some sessile solitary chlamydospores were seen. Very rarely, hyaline to brown, smooth, globose, (17-)20 $(-22) \mu \mathrm{m}$ wide, "terminal" chlamydospores, were seen on PDA; the subtending hyphae were short and consisted of a few cells.
Three isolates (55/3a, 18/1b and 210/1a) of the brown fungus were sent to Centraalbureau voor Schimmelcultures for identification and two (164/3c and 211/1a) to Dr. J.H. Warcup (Australia). Perplexingly, all the strains remained sterile and could not be identified in spite of several attempts to provoke sporulation.

The brown fungus vs. the $\mathbb{E}$ strains. The brown fungus isolated from the roots of $E$. helleborine was compared with the ectendotrophic fungi of Scots pine (strains E-15, E-24 and E-57 of Laiho 1965, Mikola 1965) (Tables 5, 6). Strains E-24 and 
Table 6. Some characteristics of the brown fungus isolated from the root pieces or hyphal coils (italics) of Epipactis helleborine. All the cultures were grown on PDA. The values (in $\mu \mathrm{m}$ ) are the means, the range being shown in brackets. $1 \mathrm{a}-\mathrm{c}$ refer to white, $2 \mathrm{a}, \mathrm{b}$ to yellowish-green and, $3 \mathrm{a}-\mathrm{c}$ to green individuals collected from Lappeenranta in 1982. K denotes a green plant from Kemiö, E-15 refers to Laiho's ectendotrophic strain. S denotes a smooth hyphal wall, $\mathrm{V}$ denotes a verrucose (ornamented) cell wall.

\begin{tabular}{|c|c|c|c|c|c|c|c|c|c|c|}
\hline \multirow[t]{2}{*}{ Plant } & \multirow[t]{2}{*}{ Code } & \multicolumn{3}{|l|}{ Hyphae } & \multicolumn{4}{|l|}{ Monilioid cells } & \multicolumn{2}{|c|}{ Chlamydospores } \\
\hline & & Diam & $\mathrm{n}$ & Wall & Length & Width & $\mathrm{n}$ & Length & Width & \\
\hline \multirow[t]{10}{*}{ White } & 207/1a & $5(3-8)$ & 28 & $\mathrm{~S} / \mathrm{V}$ & $15(9-22)$ & $14(9-22)$ & 24 & $17(12-24)$ & $17(13-22)$ & 31 \\
\hline & 208/1a & 3 & 6 & $\mathrm{~S}$ & $17(11-25)$ & $16(11-22)$ & 16 & & & \\
\hline & $210 / 1 \mathrm{a}$ & $4(3-7)$ & 20 & $\mathrm{~S}$ & $15(13-19)$ & $13(11-18)$ & 8 & $19(9-30)$ & $19(9-36)$ & 18 \\
\hline & $211 / 1 \mathrm{a}$ & $4(2-8)$ & 8 & $\mathrm{~S}$ & $20(16-24)$ & $19(11-25)$ & 17 & $22(18-26)$ & $23(15-33)$ & 5 \\
\hline & $16 * / 1 b$ & $5(2-8)$ & 21 & $\mathrm{~S}$ & $15(11-21)$ & $15(13-17)$ & 8 & & & \\
\hline & $18 / 1 b$ & $4(2-6)$ & 36 & $\mathrm{~S} / \mathrm{V}$ & $16(11-22)$ & $15(10-22)$ & 38 & $18(13-30)$ & $16(11-25)$ & 34 \\
\hline & $346 / 1 b$ & $4(2-6)$ & 24 & $S$ & $16(11-22)$ & $13(8-19)$ & 40 & $18(11-25)$ & $18(12-25)$ & 45 \\
\hline & $140 / 1 c$ & $3(2-6)$ & 11 & $S$ & $11(9-13)$ & $9(7-13)$ & 6 & $16(12-22)$ & $16(11-23)$ & 28 \\
\hline & $142 / 1 \mathrm{c}$ & $5(3-8)$ & 55 & $\mathrm{~S} / \mathrm{V}$ & $17(13-28)$ & $15(10-21)$ & 48 & $19(12-28)$ & $17(12-22)$ & 33 \\
\hline & $493 / 1 c$ & $5(3-7)$ & 73 & $\mathrm{~S} / \mathrm{N}$ & $17(11-36)$ & $12(7-19)$ & 62 & $19(14-28)$ & $18(13-28)$ & 26 \\
\hline \multirow{2}{*}{$\begin{array}{l}\text { Yellowish- } \\
\text { green }\end{array}$} & - $90 / 2 a$ & $4(2-$ & 45 & $\mathrm{~S} / \mathrm{V}$ & 17( & 12( & 37 & 19( & $18(1$ & 44 \\
\hline & $293 / 2 b$ & $4(2-6)$ & 45 & $\mathrm{~S} / \mathrm{V}$ & $15(9$ & $11(8$ & 33 & $18(12$ & $17(11$ & 51 \\
\hline \multirow[t]{8}{*}{ Green } & $55 * / 3 a$ & $4(3-7)$ & 15 & $S$ & $19(14-29)$ & $12(7-17)$ & 17 & & & \\
\hline & $48 / 3 a$ & $4(2-7)$ & 46 & $\mathrm{~S} / \mathrm{V}$ & not measured & & & $19(11-33)$ & $17(10-33)$ & 75 \\
\hline & $257 / 3 b$ & $5(2-8)$ & 43 & $\mathrm{~S} / \mathrm{V}$ & $18(12-39)$ & $15(11-20)$ & 21 & $21(17-30)$ & $20(14-30)$ & 20 \\
\hline & $164 * / 3 c$ & $4(3-6)$ & 18 & $\mathrm{~S} / \mathrm{V}$ & $17(14-22)$ & $12(9-14)$ & 12 & & & \\
\hline & $165 * / 3 c$ & $4(2-6)$ & 19 & $\mathrm{~S} / \mathrm{V}$ & $20(11-33)$ & $11(8-13)$ & 17 & $14(11-19)$ & $15(12-18)$ & 6 \\
\hline & $190 / 3 c$ & $4(2-6)$ & 29 & $\mathrm{~S} / \mathrm{V}$ & $18(14-22)$ & $15(12-18)$ & 5 & $18(12-22)$ & $16(11-25)$ & 51 \\
\hline & $542 / 3 c$ & $4(3-6)$ & 14 & $S$ & not measured & & & $19(13-25)$ & $18(13-25)$ & 6 \\
\hline & $421 / \mathrm{K}$ & $5(3-7)$ & 27 & $\mathrm{~S} / \mathrm{V}$ & $18(14-22)$ & $17(14-22)$ & 14 & $20(14-24)$ & $19(11-28)$ & 23 \\
\hline Scots pine & E-15 & $5(4-6)$ & 6 & $\mathrm{~S} / \mathrm{V}$ & $20(14-24)$ & $18(13-22)$ & 13 & $27(20-34)$ & $25(19-33)$ & 38 \\
\hline
\end{tabular}

* = Young culture (radial growth in two weeks 6 to $10 \mathrm{~mm}$ ), chlamydospores absent or rare.

E-57 were not similar to the brown endophyte of $E$. helleborine, whereas $\mathrm{E}-15$ resembled it in some characteristics. The colour of the mycelium, the hyphal diameter, the cell wall ornamentation, and the size of the monilioid cells were fairly similar (Table 6). However, E-15 showed many yeast-like monilioid cells in very long chains. Hyphae with typical terminal swellings, seen regularly in the cultures of the orchid endophyte (cf. Figs. 15, 18, 19, 23, 24), were lacking in E-15. Moreover, E-15 grew faster than the orchid endophyte on both PDA and CMA (Table 5). The numerous intercalary chlamydospores were larger, ca. $27 \times 25 \mu \mathrm{m}$ (Table 6). E-15 showed terminal verrucose chlamydospores with long subtending hyphae (typical of an E strain) when grown on both malt agar and PDA for 5 weeks (cf. Wilcox et al. 1974, Danielson 1982). The brown fungus of $E$. helleborine did not produce such "E-strain" chlamydospores on PDA, even after incubation of several months.

\section{Discussion}

A brown, slowly growing fungus was isolated 73 times from root segments of 9 individuals of Epipactis helleborine. The most suitable sterilizing chemical for obtaining the endophyte of Epipactis helleborine proved to be $0.1 \%$ mercuric chloride in $50 \%$ ethanol. The same brown fungus regularly inhabited the roots of white (chlorophyll-free), yellowishgreen, and normal green plants collected from 
Lappeenranta, and a green plant from Kemiö (over $300 \mathrm{~km}$ apart). Microscopic studies indicated that four identical isolates were also obtained from hyphal coils in cortical cells of both white and green individuals. The growth of the same fungus from all these sources strongly suggests that this brown fungus is an endophyte of the orchid. It is not yet known whether the fungus stimulates the germination of the seeds of E. helleborine. Experiments on such symbiosis obviously require both fresh seeds and recently isolated endophytes, as it is known that some orchid endophytes rapidly lose their symbiotic activity in culture (Alexander \& Hadley 1983).

The strains of the brown fungus did not produce fruiting bodies. Without the teleomorph, identification of orchid fungi is extremely difficult (cf. Filipello Marchisio et al. 1985). In growth pattern and microscopic characteristics, the endophyte of $E$. helleborine differs from other well-known orchid-inhabiting Rhizoctonias, e.g. $R$. goodyerae repentis (Ceratobasidium cornigerum), $R$. repens (Tulasnella calospora), $R$. solani (Thanatephorus cucumeris). Features very typical of the isolated brown fungus were the tardy start of growth and slow subsequent development of the mycelia on PDA and CMA. Most orchid endophytes (especially Rhizoctonias) grow rapidly and can, moreover, be isolated after incubation of 2-3 days (Burges 1939, Warcup 1981b). According to Dr. J.H. Warcup (pers. comm.), the present brown fungus is no "usual" Rhizoctonia. Dr. Warcup has isolated fairly similar mycelia from ascocarps that are mycorrhizal with pines. With his encouragement, the brown fungus isolated from the roots of $E$. helleborine was compared with some "E strains" (Laiho 1965, Mikola 1965) of an ectendotrophic fungus of Scots pine. Interestingly, one of them $(\mathrm{E}-15)$ resembled the endophyte in some characteristics. However, my fungal strains never produced typical terminal verrucose chlamydospores of the E-strain type (cf. Wilcox et al. 1974, Danielson 1982). Such chlamydospores are diagnostic (Yang \& Wilcox 1984) of ectendotrophic fungi which have an ascomycetous teleomorph (Wilcoxina mikolae, cf. Yang \& Korf 1985). This suggests that, although rather similar, the endophyte and E-15 are not identical.

To my knowledge, endophytes of $E$. helleborine or other Epipactis species have not been isolated before (cf. Nishikawa \& Ui 1976, Scrugli et al. 1986). Nieuwdorp (1972, and pers. comm.) tried to obtain the endophyte of $E$. helleborine but failed, probably due to too mild surface sterilization (with ethanol) of the roots. The results presented here clearly show that the surface-sterilizing method is extremely important in obtaining the endophyte and other fungi occupying the roots either externally or internally. For instance, in the preliminary isolation experiments (Lappeenranta/1981) the brown fungus did not appear, although the plants were heavily infected by the endomycorrhizal fungus (Salmia 1989). The roots of the two specimens from Kemiö also showed intensive endomycorrhizal infection (Salmia 1989), but the brown fungus occurred only once in the isolation experiments. The reason for this poor result may be collection very late in the season (October for Kemiö/1982), and inactivity of the fungus. The short viability of the hyphae (see Mollison 1943, Hadley \& Williamson 1971) is probably another reason (Lappeenranta/1981, Kemiö 1982).

The present results indicate that the same fungus can be isolated from hyphal coils in infected cortical cells and from root segments of E. helleborine. Hyphal coils have been preferred to root segments by many authors (Bernard 1909, Burges 1939, Warcup and Talbot 1967, Hadley 1970, Warcup 1971, 1981b, 1985, Terashita 1982). When root segments are used as a source of the endophyte, large numbers of isolations can be made rapidly, whereas the method of isolation from hyphal coils is more laborious. However, the root segment method may allow occasional transfer of root surface (rhizosphere) or intercellular contaminants. For this reason strong surface-sterilizing of root pieces is needed to obtain the endophyte. When endophytic fungi are isolated from hyphal coils no strong surface-sterilizing liquids are needed. The most suitable sterilization chemical for obtaining the endophyte of $E$. helleborine proved to be mercuric chloride in $50 \%$ ethanol.

The specificity of the relationship between the host and its endophyte has been studied in several orchids (Curtis 1939, Harvais \& Hadley 1967, Hadley 1970, Warcup 1971, 1981a, Terashita 1982). Older roots of some orchids, in particular, may carry a variety of fungi as endophytes within their tissues (Mollison 1943, Downie 1959, Warcup 1975, 1981b). For instance, Dactylorchis purpurella can harbour a range of Rhizoctonia species in its roots (Downie 1959, Harvais \& Hadley 1967). Two Rhizoctonias (R. repens and $R$. solani) have been isolated from hyphal coils in roots of Spiranthes sinensis var. amoena (Terashita 1982). On the other hand, the natural endophyte of Goodyera repens always seems to be a single fungus, Ceratobasidium cornigerum (Downie 1940, Hadley 1970, Alexander \& Hadley 1983). The results obtained in the present study indicate that the natural endophyte of $E$. helleborine (of Lappeenranta and Kemiö) is evidently the same fungus, but its identity is not yet known.

During the protocorm stage all orchids, be they chlorophyllous (green) or achlorophyllous as adults, 
are unable to photosynthesize and must obtain carbohydrates from their fungal partners. They may be dependent on their mycorrhizal fungus for some period of their plantlet stage also (Alexander \& Hadley 1985). The degree to which green orchids are mycorrhizal as adults is likely to vary. Usually they have mycorrhizal roots but in some species infection is reported to be sporadic or may be absent (literature cited in Salmia 1989). It is not clear how long the orchids may or must derive carbohydrates from their fungal partners after they have produced green leaves (Harley \& Smith 1983). Some orchids can remain subterranean for years (Summerhayes 1951, Wells 1967, Tamm 1972). This implies that some terrestrial orchids must continue to obtain carbon through the fungus. Recently, however, Alexander and Hadley (1985) reported that mature green plants of Goodyera repens appear to be carbon-independent. The roots of all investigated green and white individuals of $E$. helleborine have been shown to be regularly infected (Salmia 1989). Obviously, the white achlorophyllous plants would not survive without the carbohydrates supplied by the fungal partner. It is not certain whether the presence of the endophyte is also essential to mature, green $E$. helleborine.

A few genera of terrestrial orchids (incl. Neottia, Corallorhiza, Rhizanthella) and some of the largest orchid lianes (Galeola, Gastrodia) are achlorophyllous. These orchids can be regarded as parasitic on the fungus through digestion and lysis of the fungus ("nectrotrophic" hypothesis, cf. Hadley 1986). Alternatively, triple symbiosis (also called epiparasitism, Smith et al. 1969, Furman \& Trappe 1971 or epiphytosis, Ruinen 1953) may occur. The endotrophic fungus of an achlorophyllous orchid is then associated, parasitically or mutualistically with another, autotrophic plant. In triple symbiosis, the carbon has a pathway from the autotrophic plant via the fungus to the heterotrophic orchid. Campbell $(1962,1963$, 1964,1970 ) has described such arrangements for three species in the non-green orchid genera of Gastrodia and Corallorhiza. For example, Gastrodia cunninghamii is epiparasitic on the roots of forest trees via Armillaria mellea (Campbell 1962). An undescribed species of Rhizoctonia forms hyphal coils within Rhizanthella gardneri, which is a rare subterranean achlorophyllous orchid, and also has a close association, ectomycorrhiza and Hartig net, with a Myrtaceous shrub (Warcup1985).

$E$. helleborine has a very wide distribution throughout Europe. It is characteristic of beech- and oakwoods and pine plantations (Summerhayes 1951). Interestingly, Weijer (1952) noticed that in areas where pine exists, $E$. helleborine is a regular companion. He suggested that pine possibly plays an important role in the terms of existence of Epipactis. This seems to be the situation in the present case: Scots pine is the dominant tree in the study areas of Kemiö and Lappeenranta. The source of carbon for white plants of $E$. helleborine has not yet been investigated. If it is a question of triple symbiosis, the role of Scots pine must first be studied. Dr. J.H. Warcup (pers. comm.) noted that the present brown fungus isolated from the roots of $E$. helleborine can form definite, albeit rather poor, ectomycorrhizas with the pines tested (Pinus radiata, $P$. kesiya). Such mycorrhizal studies have not yet been made with Scots pine. Neither is it known whether the same fungus can be isolated from the roots of Scots pine. The whole question deserves further investigation.

Acknowledgements. I thank Dr. J.H. Warcup (University of Adelaide, Australia) for valuable notes and cooperation during the study. I am grateful to the following three persons from the University of Helsinki: Dr. Tuomo Niemelä for helpful discussions during the preparation of the manuscript, Mrs Hilkka Koponen, Cand. Phil., for help in the identification of the different soil fungi, and Mr Kurt Fagerstedt, Ph.D., for skilful technical assistance. I also thank Mr Ben Lindén for collecting for me the two samples of $E$. helleborine from Kemiö. The ectendotrophic strains (E-15, E-24 and E-57) used for comparative studies were obtained from collections of the Department of Microbiology, University of Helsinki. The English was revised by Mrs Anna A. Damström, M. A. This study was supported by grants from Oskar Öflund's Foundation and the Niilo Helander Foundation.

\section{References}

Alexander, C. \& Hadley, G. 1983: Variation in symbiotic activity of Rhizoctonia isolates from Goodyera repens mycorrhizas. - Trans. British. Mycol. Soc. 80: 99-106.

- 1985: Carbon movement between host and mycorrhizal endophyte during the development of the orchid Goodyera repens Br. - New Phytol. 101: 657-665.

Arditti, J. 1979: Aspects of the physiology of orchids. In: Woolhouse, H.W. (ed.), Adv. Bot. Res. 7: 421-655. London.

Barroso, J., Chaves Neves, H. \& Pais, M.S.S. 1986a: Ultrastructural, cytochemical and biochemical aspects related to the formation of $\mathrm{O}$. lutea endomycorrhizae. - In: Gianinazzi-Pearson, V. \& Gianinazzi, S. (eds.), Mycorrhizae, physiology and genetics, 1st ESM, Dijon, 1-5 July 1985: 265-269. Paris.

- 1986b: Isolation and chemical characterization of odd fatty acids present in Ophrys lutea roots during invasion of the endophyte. - In: Gianinazzi-Pearson, V. \& Gianinazzi, S. (eds.), Mycorrhizae, physiology and genetics, 1st ESM, Dijon, 1-5 July 1985: 436-440. Paris.

Bernard, N. 1909: L'évolution dans la symbiose. Les orchidées et leur champignons commensaux. - Ann. Sci. Nat. Bot. 9: 1-196.

Booth, C. 1966: The genus Cylindrocarpon. - Mycol. Papers: 104: 1-56. 
Burgeff, H. 1936: Samenkeimung der Orchideen und Entwicklung ihrer Keimpflanzen. - 312 pp. Jena.

- 1959: Mycorrhiza of orchids. - In: Withner, C.L. (ed.), The orchids, a scientific survey: 361-395. New York.

Burges, A. 1939: The defensive mechanism in orchid mycorrhiza. - New Phytol. 38: 273-283.

Campbell, E.O. 1962: The mycorrhiza of Gastrodia cunninghamii Hook. f. - Trans. Roy. Soc. New Zealand 1: 289-296.

- 1963: Gastrodia minor Petrie, an epiparasite of manuka. Trans. Roy. Soc. New Zealand 2: 73-81.

- 1964: The fungal association in a colony of Gastrodia sesamoides R. Br. - Trans. Roy. Soc. New Zealand 2: 237 246.

- 1970: Morphology of the fungal association in three species of Corallorhiza in Michigan. - Michigan Botanist 9: 108-113.

Currah, R.S. 1987: Thanatephorus pennatus sp. nov. isolated from mycorrhizal roots of Calypso bulbosa (Orchidaceae) from Alberta. - Canad. J. Bot. 65: 1957-1960.

Curtis, J.T. 1939: The relation of specificity of orchid mycorrhizal fungi to the problem of symbiosis. - Amer. J. Bot. 26: 390-399.

Danielson, R.M. 1982: Taxonomic affinities and criteria for identification of the common ectendomycorhizal symbionts of pines. - Canad. J. Bot. 60: 7-18.

Domsch, K.H., Gams, W. \& Anderson, T.-H. 1980: Compendium of soil fungi vol. I, $859 \mathrm{pp}$. London.

Downie, D.G. 1940: On the germination and growth of Goodyera repens. - Trans. Bot. Soc. Edinburgh 33: 3651.

- 1943: Source of the symbiont of Goodyera repens. Trans. Bot. Soc. Edinburgh 33: 383-390.

- 1957: Corticium solani- an orchid endophyte. - Nature 179: 160.

- 1959: The mycorrhiza of Orchis purpurella. - Trans. Bot. Soc. Edinburgh 38: 16-29.

Dreyfuss, M. \& Petrini, O. 1984: Further investigations on the occurrence and distribution of endophytic fungi in tropical plants. - Bot. Helvetica 94: 33-40.

Filipello Marchisio, V., Berta, G., Fontana, A. \& Marzetti Mannina, F. 1985: Endophytes of wild orchids native to Italy: their morphology, caryology, ultrastructure and cytochemical characterization. - New Phytol. 100: 623-641.

Furman, T.E. \& Trappe, J.M. 1971: Phylogeny and ecology of mycotrophic achlorophyllous angiosperms. Q. Rev. Biol. 46: 219-225.

Gams, W., van der Aa, H.A., van der PlaatsNiterink, A.J., Samson, R.A. \& Stalpers, J.A. 1980: CBS course of mycology, 2nd ed. - 110 pp. Amsterdam.

Hadley, G. 1970: Non-specificity of symbiotic infection in orchid mycorrhiza. - New Phytol. 69: 1015-1023.

- 1982. Orchid mycorrhiza. - In: Arditti, J. (ed.), Orchid biology, reviews and perspectives II: 83-118.

- 1986: Mycorrhizas of heterotrophic plants. - In: Gianinazzi-Pearson, V. \& Gianinazzi, S. (eds.), Mycorrhizae, physiology and genetics, 1st ESM, Dijon, 1-5 July 1985: 815-819. Paris.

Hadley, G. \& Williamson, B. 1971: Analysis of the post-infection growth stimulus in orchid mycorrhiza. New Phytol. 70: 445-455.

Hall, I.R. 1976: Vesicular mycorrhizas in the orchid Corybas macranthus. - Trans. British Mycol. Soc. 66: 160.
Hamada, M. 1940: Studien über die Mykorrhiza von Galeola septentrionalis Reichb. f., Ein neur Fall der MykorrhizaBildung durch intraradicale Rhizomorpha. - Japan. J. Bot. 10: 151-212.

Hamada, M. \& Nakamura, S.I. 1963: Wurzelsymbiose von Galeola altissima Reichb. F., einer chlorophyllfreien Oxchidee, mit dem holzzerstörenden Pilz Hymenochaete crocicreas Berk. et Br. - Sci. Rep. Tohoko Univ. Ser 4 (Biol.) 29: 227-238.

Harley, J.L. 1969: The biology of myconhiza 2nd ed. 334 pp. London.

Harley, J.L. \& Smith, S.E. 1983: Mycorrhizal symbiosis. - $483 \mathrm{pp}$. London.

Harvais, G. 1974: Notes on the biology of some native orchids of Thunder Bay, their endophytes and symbionts. - Canad. J. Bot. 52: 451-460.

Harvais, G. \& Hadley, G. 1967: The relation between host and endophyte in orchid mycorrhiza. - New Phytol. 66: 205-215.

Jonsson, L. \& Nylund, J.E. 1979: Favolaschia dybowskyana (Singer) Singer (Aphyllophporales), a new orchid mycorrhizal fungus from tropical Africa. - New Phytol. 83: 121-128.

Laiho, O. 1965: Further studies on the ectendotrophic mycorrhiza. - Acta For. Fennica 79(3): 1-35.

Lundkvist, N. 1972: Nordic Sordariaceae s. lat. - Symb. Bot. Upsal. 20: 1-374.

Mikola, P. 1965: Studies of the ectendotrophic mycorrhiza of pine. - Acta For. Fennica 79 (2): 1-56.

Mollison, J.E. 1943: Goodyera repens and its endophyte. - Trans. Bot. Soc. Edinburgh 33: 391-403.

Nieuwdorp, P.J. 1972: Some observations with light and electron microscope on the endotrophic mycorrhiza of orchids. - Acta Bot. Neerl. 21: 128-144.

Nishikawa, T. \& Ui, T. 1976: Rhizoctonias isolated from wild orchids in Hokkaido. - Trans. mycol Soc. Japan 17: 77-84.

Parmeter, J.R. Jr. \& Whitney, H.S. 1970: Taxonomy and nomenclature of the imperfect state. - In: Parmeter, J.R. Jr. (ed.), Rhizoctonia solani, biology and pathology: 7-31. Berkeley.

Petrini, O. \& Dreyfuss, M. 1981: Endophytische Pilze in Epiphytischen Araceae, Bromeliaceae und Orchidaceae. - Sydowia Ann. Mycol. 34: 135-148.

Ruinen, J. 1953: Epiphytosis. A second view on epiphytism. - Ann. Bogor. 1: 101-157.

Salmia, A. 1986: Chlorophyll-free form of Epipactis helleborine (Orchidaceae) in SE Finland. - Ann. Bot. Fennici 23: 49-57.

- 1989: Features of endomycorrhizal infection of chlorophyllfree and green forms of Epipactis helleborine (Orchidaceae). - Ann. Bot. Fennici 26: (in press).

Scrugli, A., Riess, S. \& Melis, F. 1986: Contributo alla conoscenza delle micorrize nelle Orchidaceae della Sardegna. - Mic. Ital. 1986, 1: 61-68.

Smith, D., Muscatine, L. \& Lewis, D. 1969: Carbohydrate movement from autotrophs to heterotrophs in parasitic and mutualistic symbiosis. - Biol. Rev. 44: 17-90.

Smith, S.E. 1966: Physiology and ecology of orchid mycorrhizal fungi with reference to seedling nutrition. New Phytol. 65: 488-499.

Summerhayes, V.S. 1951: Wild orchids of Britain. - 366 pp. London.

Tamm, C.O. 1972: Survival and flowering of some perennial herbs 2 . The behaviour of some orhids on permanent plots. - Oikos 23: 23-28. 
Terashita, T. 1982: Fungi inhabiting wild orchids in Japan 2. Isolation of symbionts from Spiranthes sinensis var. amoena. - Trans. Mycol. Soc. Japan 23: 319-328.

- 1985: Fungi inhabiting wild orchids in Japan 3. A symbiotic experiment with Armillariella mellea and Galeola septentrionalis. - Trans. Mycol. Soc. Japan 26:47-53.

Tu, C.C. \& Kimbrough, J.W. 1975: Morphology, development, and cytochemistry of the hyphae and sclerotia of species in the Rhizoctonia complex. - Canad. J. Bot. 53: 2282-2296.

- 1978: Systematics and phylogeny of fungi in the Rhizoctonia complex. - Bot. Gaz. 139: 454-466.

Warcup, J. H. 1971: Specificity of mycorrhizal association in some Australian terrestrial orchids. - New Phytol. 70: 41-46.

- 1975: Factors affecting symbiotic germination of orchid seed. - In: Sanders, F.E., Mosse, B. \& Tinker, P.B. (eds.), Endomycorrhizas: 85-104. London.

- 1981a: The mycorrhizal relationships of Australian orchids. - New Phytol. 87: 371-381.

- 1981b: Orchid mycorrhizal fungi. - In: Lawle, L. \& Kerr, R.D. (eds.), Proceedings of the orchid symposium held as a satellite function of the 13th International Botanical Congress, Sydney, Australia: 57-63. Sydney.

- 1985: Rhizanthella gardneri (Orchidaceae), its Rhizoctonia endophyte and close association with Melaleuca uncinata (Myrtaceae) in western Australia. - New Phytol. 99: 273-280.

Warcup, J.H. \& Talbot, P.H.B. 1962: Ecology and identity of mycelia isolated from soil. - Trans. British Mycol. Soc. 45: 495-518.

- 1965: Ecology and identity of mycelia from soil 3. Trans. British mycol. Soc. 48: 249-259.

- 1966: Perfect states of some Rhizoctonias. - Trans. British Mycol. Soc. 49: 427-435.

- 1967: Perfect states of Rhizoctonias associated with orchids. - New Phytol. 66:631-641

- 1971: Perfect states of Rhizoctonias associated with orchids 2. - New Phytol. 70: 35-40.

- 1980: Perfect states of Rhizoctonias associated with orchids 3. - New Phytol. 86: 267-272.

Weijer, J. 1952: The colour-differences in Epipactis helleborine (L.) Cr. Wats. \& Coult., and the selection of the genetical varieties by environment. - Genetica 26: 1-32.

Wells, T.C.E. 1967: Changes in a population of Spiranthes spiralis (L.) Chevall. at Knocking Hoe National Reserve, Bedfordshire. - J. Ecol. 55: 83-99.

Whitney, H.S. \& Parmeter, J.R. Jr. 1964: The perfect stage of Rhizoctonia hiemalis. - Mycologia 54: 114118.

Wilcox, H.E., Ganmore-Neumann, R. \& Wang, C.J.K. 1974: Characteristics of two fungi producing ectendomycorrhizae in Pinus resinosa. - Canad. J. Bot. 52: 2279-2282.

Yang, C.S. \& Korf, R.P. 1985: A monograph of the genus Tricharina and a new segregate genus, Wilcoxina (Pezizales). - Mycotaxon 24: 467-531.

Yang, C.S. \& Wilcox, H.E. 1984: An E-strain ectendomycorrhiza formed by a new species, Tricharina mikolae. — Mycologia 76: 675-684.

Accepted for publication

on 29 February 1988 